ISSN 1991- 8690

Website: http://jsci.utq.edu.iq
الترقيم الدولي 8690 - 2091

Email: utjsci@utq.edu.iq

\title{
Effect of Hyperprolactinaemia on level of testosterone in a series of infertile Iraqi men
}

\author{
ENAS ABDUL KAREEM JABAR \\ Department of Biology - College of Science - Thi - qar University
}

\begin{abstract}
The present study was designed to detect the level of testosterone due to by hyperprolactinaemia 20 patients, who were attending the civil laboratories in nassrya city for diagnosis and treatment the reasons of infertility during the period November 2008 February 2010.

Primary infertile males patients with hyperprolactinaemia (age range: $20-50$ years) were investigated. The collected serum was tested for the determination of prolactin levels using a miniVidas system. (serum level of prolactin $\leq 19 \mathrm{ng} / \mathrm{ml}$ ), and were investigated level of testosterone the level was assayed sing a miniVidas system too serum level of testosterone $\geq 10 \mathrm{ng} / \mathrm{ml}$ the testosterone level showed a significant decreased total level in the sera of total patients when compared with controls and with hyperprolactinaemia patients.
\end{abstract}

\section{Introduction}

Infertility is defined as the failure to achieve a pregnancy after one year of regular (at least twice weekly) unprotected intercourse with the partner. Male infertility is diagnosed when, after testing of both partners, reproductive problems have been identified in the male partner which include: Nerve damage following spinal cord injury, diabetes, or surgery to the prostate or pelvis can prevent erection and ejaculation. Some drugs to treat depression or high blood pressure may also cause erection and ejaculation problems. Sexual problems are not a common cause of infertility and affect less than one in 100 infertile men. (Lynskey ., 1991). One in eight women has difficulty becoming pregnant and is
Considered infertile In about one in five infertile women the problem lies solely in the male partner (male infertility).

Male infertility is the underlying reason for $40 \%$ of infertile couples using assisted reproduction technologies Infertility in men is most often caused by: A problem called varicocele (VAIRih-koh-seel) this happens when the veins on a man's testicles are too large. This heats the testicles the heat can affect the number or shape of the sperm. Other factors that cause a man to make too few sperm or none at all. Movement of the sperm this may be caused by the shape of the sperm. Sometimes injuries or other damage to the reproductive system block the sperm. Sometimes a man is born with the problems that affect his 
sperm. Other times problems start later in life due to illness or injury. For example, cystic fibrosis often causes infertility in men. ( Butt .,1988). With the results of medical tests, the doctor may be able to identify the cause of a man's fertility problems.

The following are known causes of male infertility:

- Sperm Production Problems: The most common cause of male infertility is due to a problem in the sperm production process in the testes. About two thirds of infertile men have sperm production problems. Low numbers of sperm are made and/or the sperm that are made do not work properly. A number of factors can disrupt the production of sperm including undescended testis, infections such as mumps, heat, sperm antibodies, torsion, varicocele, drugs or radiation damage. (Conn PM, Goodman HM., 1997).

-Blockage of sperm transport: Blockages (obstructions) in the tubes leading sperm away from the testes to the penis can cause a complete lack of sperm in the ejaculated semen. This is the second most common cause of male infertility and affects about three in every 20 infertile men, including men with the common problem of having an earlier vasectomy. (Thomson RC ., 1998).

-Sperm antibodies: In some men, sperm antibodies can develop which can lessen sperm movement and block egg binding during fertilisation. About one in every 16 infertile men has sperm antibodies. (Jones LA, et al ., 2008 ).

-Sexual problems: Difficulties with sexual intercourse, such as erection or ejaculation problems, can also prevent couples from becoming pregnant (Malarkey WB.,1998).

- impotence
-Hormonal Problems: Sometimes the pituitary gland, located underneath the brain, does not send the right messages to the testes. This can cause low testosterone levels, which means that sperm are not produced hormonal causes are uncommon, and affect less than one in 100 infertile men anabolic (androgenic) steroid abuse by body builders can shut off the hormones from the pituitary and lead to low sperm counts( W. A. Brown etal., 1981 ).

hormonal imbalances : which cause the reproductive system to function abnormally The hormone prolactin is generally only thought of as afactor in female infertility, but in fact, prolactin also plays a role in male fertility Unfortunately, it is unclear what role prolactin plays in men (Molitch, M. E. (2001) . However, it is evident that prolactin and infertility are linked In fact, if you have too much prolactin in your blood stream it can cause you to become infertile High prolactin levels have an adverse affect on the function of your testicles, and can cause decreased testosterone levels or abnormal sperm indicate a condition called hyperprolactinemia, and this could account for your fertility difficulties You can be diagnosed with hyperprolactinemia when you have more than $19 \mathrm{ng} / \mathrm{mL}$ of prolactin in your blood stream Symptoms of excess prolactin are often internal and difficult to see.

(Luciano, A. A., 1999).

Symptoms can include:

- decreased sperm count

- hypogonadism (in which your testes do not produce the right amounts of testosterone)

- decreased sex drive

- decrease in body hair ( C. Bole-Feysot et al.,1998). 
Causes of High Prolactic Levels:

Elevated prolactin levels in men are usually the result of overactive prolactin cells in the pituitary gland. These cells begin to grow into a tumor, called a prolactinoma, on your pituitary gland.

Prolactinomas secrete prolactin hormone, and, as a result, can lead to extremely high levels of the hormone in your body. Prolactinomas in men are often larger than in women, mostly because the symptoms of the disorder are more difficult to recognize in men. Prolactinomas In fact, prolactinomas can grow up to $5 \mathrm{~cm}$ in width and, if untreated, can leave you permanently infertile.Occasionally, other factors may play a role in elevating your prolactin levels prescription medications (like antidepressants and opiates),thyroid disease , shingles (J. Axelsson etal.,2003 ) there are treatments available to you Dopamine-producing medication: these medications can lower prolactin levels and shrink prolactinomas, Surgery: surgery is sometimes used to reduce the size of a prolactinoma ( C. Bole-Feysot et al.,1998). There are still gaps in our knowledge and for $40 \%$ of men with male infertility, the cause of the problem is unknown. This is called 'idiopathic infertility' or 'cause unknown'.

\section{Material and methods:}

Primary infertile male patients with hyperprolactinaemia (age range: $20-50$ years) were investigated. Based on serum level of prolactin (PRL) and testosterone $(\mathrm{T})$, the total patients (20 hyper-prolactinaemic males).

1-Measured the concentration of prolactin hormone in blood serum:-

Their serum prolacin levels were (10- 19 $\mathrm{ng} / \mathrm{ml}$ ), respectively. with 20 fertile males The collected serum was tested for the determination of prolactin levels using aminiVidas system wich is importing by Biomerieux SA company France wich is contain from:-

\section{1-The kit witch is content (60 testes) reconstitution of reagents:}

\begin{tabular}{|c|c|c|}
\hline GOPRL STRTPS & STR & READY TO USE \\
\hline $\begin{array}{l}60 \text { PRI SPRs (solid } \\
\text { phase receptacles) } 2 \times 30\end{array}$ & SPR & $\begin{array}{l}\text { Ready to use. } \\
\text { Interior of SPRs coated with monoclonal anti-prolactin } \\
\text { immunoglobulins (mouse). }\end{array}$ \\
\hline $\begin{array}{l}\text { PRI control } 1 \times 3 \quad \mathrm{ml} \\
\text { (1yophilized) }\end{array}$ & C1 & $\begin{array}{l}\text { Reconstitute with } 3 \mathrm{ml} \text { of distilled water. Wait for } 5 \text { to } \\
10 \text { minutes. Mix after reconstitution, stable } 24 \text { hours at } \\
2-8 \mathrm{C}^{\circ} \text { or until the expiration date on the kit when } \\
\text { stored at }-25 \pm 6 \mathrm{C}^{\circ} 5 \text { freeze } / \text { thaw cycle are possible. } \\
\text { Human serum }+ \text { human prolactin }+ \text { chemical stabilizer. } \\
\text { The confidence interval in } \mathrm{ng} / \mathrm{m} 1 \text { is indicated on the } \\
\text { MIE card after the following mention "control C1 dose } \\
\text { value range". }\end{array}$ \\
\hline $\begin{array}{l}\text { PRL calibrator } 3 \times 2 \mathrm{ml} \\
\text { ( lyophilized) }\end{array}$ & S1 & $\begin{array}{l}\text { Reconstitute with } 3 \mathrm{~m} \text { of distilled water. Wait for } 5 \text { to } \\
10 \text { minutes. Mix after reconstitution, stable } 24 \text { hours at } \\
2-8 \mathrm{Co} \text { or until the expiration date on the kit when } \\
\text { stored at }-25 \pm 6 \mathrm{C}^{\circ} 5 \text { freeze } / \text { thaw cycle are possible. } \\
\text { Human serum }+ \text { human prolactin }+ \text { chemical stabilizer. } \\
\text { The concentration in ng/m1 is indicated on the MLE } \\
\text { card after the following mention "calibrator S1 dose } \\
\text { value range". The confidence interval in "Relative } \\
\text { Fluorescence value" in indicated on the MLE card after } \\
\text { the following mention "calibrator S1RFV range ". }\end{array}$ \\
\hline Diluent $1 \times 3 \mathrm{ml}$ (liquid) & R1 & $\begin{array}{l}\text { Ready to use }> \\
\text { Human serum }+1 \mathrm{~g} / 1 \text { sodium azide. }\end{array}$ \\
\hline \multicolumn{2}{|c|}{ INLL card (Master Lot Entry) } & $\begin{array}{l}\text { Specifications she et containing the factory master } \\
\text { calibration data required to calibirate the test. }\end{array}$ \\
\hline
\end{tabular}


2- the strip of prolactin (PRL) :- Description of PRL strip

\begin{tabular}{|c|c|}
\hline WELLS & "REAGENTS \\
\hline 1 & Sample well \\
\hline $2-3-4-5$ & Empty wells \\
\hline 6 & $\begin{array}{l}\text { Conjugate: Alkaline phosphatase-labelled monoclonal anti- } \\
\text { prolactin immunoglobulin (mouse) }+1 \mathrm{~g} / 1 \text { sodium azide ( } 400 \\
\text { H). }\end{array}$ \\
\hline $7-8$ & $\begin{array}{l}\text { Wash buffer: Sodium phosphate }(0.01 \mathrm{~mol} / 1, \mathrm{PH} 7.4)+1 \mathrm{~g} / \mathrm{l} \\
\text { sodium azide }(600 \mu 1) \text {. }\end{array}$ \\
\hline 9 & $\begin{array}{l}\text { Wash buffer: diethanolamine }(1.1 \mathrm{~mol} / 1 \text { or } 11.5 \%, \mathrm{PH} 9.8)+ \\
1 \mathrm{~g} / 1 \text { sodium azide }(600 \mu 1) \text {. }\end{array}$ \\
\hline 10 & $\begin{array}{l}\text { Reading cuvette with substrate: } 4 \text { Methyl-umbelliferyl- } \\
\text { phosphate }(0.6 \mathrm{mmol} / \mathrm{l})+\text { diethanolamine (DEA) }(0.62 \mathrm{~mol} / 1 \\
\text { or } 6.6 \% \mathrm{PH} 9.2)+1 \mathrm{~g} / 1 \text { sodium azide }(300 \mu 1) .\end{array}$ \\
\hline
\end{tabular}

\section{PRINCIPLE:-}

The assay principle combines an enzyme immunoassay sandwich method with afinal fluorescent detection (ELFA).The solid phase receptacle (SPR) serves as the solid phase as well as the pipetting device for the assay .

Reagent for the assay ready to use and predispensed in the seald reagent strips . All of the assay steps are performed automatically by the instrument. The reaction medium is cycled in and out of the SPR several times. The sample is taken and transferred into the well containing alkaline-phosphatase labeled anti-prolactin (conjugate) the sample/conjugate mixture in and out of the SPR several time to increase the reaction speed the antigen binds to antibodies coated on the SPR and to the conjugate forming a sandwich .Unbound components are eliminated during the washing steps during the final detection step the substrate (4-Methyl-umbelliferyl phosphate ) is cycled in and out of the SPR the conjugate enzyme catalyzed the hydrolysis of this substrate into a fluorescent production (4-Methylumbelliferone)the fluorescence of wich is measured at $450 \mathrm{~nm}$ the intensity of the fluorescence is proportional to the concentration of prolactin present in the sample .

At the end pf the assay results are automatically calculated by the instrument in relation to the calibration curve stored in memory and then printed out.

\section{Methods:-}

1- Only remove the required reagents from the refrigerator and allow them to come to room temperature for at least 30 minutes.

2- use one PRL strip and one PRL SPR for each sample control or calibrator to be tasted . 
3- type or select PRL to enter the test code the calibrator must be identified by $\mathrm{S} 1$ and tasted in duplicate if the control is to be tasted it should be identified by $\mathrm{C} 1$.

4- If necessary clarify samples by centrifugation.

5- Mix the calibrator control and sample using a vortex type mixer

6- Pipette $200 \mu 1$ of sample calibrator or control into the sample well.

7- Insert the SPRs and strip into the instrument check to make sure the color labels with the assay code on the SPRs and the reagent strips match .

8- Initial the assay as directed in the Operator's manual all the assay steps are performed automatically by the instrument the assay well be completed within approximately 40 minutes.

9- After the assay is completed remove the SPRs and strips from the instrument.

10-Dispose of the used SPRs and strips into an appropriate recipient .

2-Measured the concentration of testosterone hormone in blood serum:Their serum testosterone levels were $(\leq 3-10 \mathrm{ng} / \mathrm{ml})$, respectively. with 20 fertile males The collected serum was tested for the determination of testosterone levels using aVidas system wich is importing by Biomerieux SA company France wich is contain from:-

\section{1- The kit wich is content (30 testes ) reconstitution of reagents :}

\begin{tabular}{|c|c|c|}
\hline 30TES STRTPS & "STR & READY TO USE \\
\hline 30 TES SPRs $1 \times 30$ & SPR & $\begin{array}{l}\text { Ready to use. } \\
\text { SPRs sensitized with polyclonal anti-testosterone } \\
\text { immunoglobulins (rabbit). }\end{array}$ \\
\hline $\begin{array}{l}\text { TES control } 1 \times 2 \mathrm{ml} \\
\text { (lyophilized) }\end{array}$ & C1 & $\begin{array}{l}\text { Reconstitute with } 2 \mathrm{ml} \text { of distilled water. Wait for } 5 \text { to } \\
10 \text { minutes. Mix after reconstitution, stable } 2 \text { weeks at } \\
2-8 \mathrm{C}^{\circ} \text { or until the expiration date on the kit when } \\
\text { stored at }-25 \pm 6 \mathrm{C}^{\circ} \text {. } 5 \text { freeze / thaw cycle are possible. } \\
\text { Human serum }+ \text { testosterone }+ \text { preservatives. } \\
\text { The confidence interval in } \mathrm{ng} / \mathrm{ml} \text { is indicated on the } \\
\text { MIE card after the following mention "contro } 1 \mathrm{C} 1 \text { dose } \\
\text { value range". }\end{array}$ \\
\hline $\begin{array}{l}\text { TES calibrator } 1 \times 3 \mathrm{ml} \\
\text { ( lyophilized) }\end{array}$ & S1 & $\begin{array}{l}\text { Reconstitute with } 2 \mathrm{ml} \text { of distilled water. Wait for } 5 \text { to } \\
10 \text { minutes. Mix after reconstitution, stable } 2 \text { weeks at } \\
2-8 \mathrm{C}^{\circ} \text { or until the expiration date on the kit when } \\
\text { stored at }-25 \pm 6 \mathrm{C}^{\circ} \text {. } 5 \text { freeze / thaw cycle are possible. } \\
\text { Human serum }+ \text { testosterone }+ \text { preservatives. } \\
\text { The concentration in ng/ml is indicated on the MLE } \\
\text { card after the following mention "calibrator S1 dose } \\
\text { value range". The confidence interval in "Relative } \\
\text { Fluorescence value" is indicated on the MLE card after } \\
\text { the following mention "calibrator S1RFV range ". }\end{array}$ \\
\hline IMLE card (Master Lot & Entry) & $\begin{array}{l}\text { Specifications sheet containing the factory master } \\
\text { calibration data required to calibirate the test. }\end{array}$ \\
\hline
\end{tabular}


2- The strip of testosterone (TES) :-description of TES strip

\begin{tabular}{||l|l||}
\hline WELLS & REAGENTS \\
\hline $\mathbf{1}$ & Sample well \\
\hline $\mathbf{5}$ & Empty wells \\
\hline $\mathbf{6}$ & $\begin{array}{l}\text { Conjugate: Alkaline phosphatase-labelled testosterone derivative + } \\
\text { calf serum+ gelatin (porcine) + releasing agent }+0.9 \text { g/1 sodium } \\
\text { azide }(400 \mu 1) .\end{array}$ \\
\hline $\mathbf{7 - 8}$ & Empty wells \\
\hline $\mathbf{9}$ & $\begin{array}{l}\text { Wash buffer: Tris-Nacl (0.05 mol } / 1) \text { PH } 7.8+0.9 \text { g/1 sodium } \\
\text { azide (600 } \mu 1) .\end{array}$ \\
\hline $\mathbf{1 0}$ & $\begin{array}{l}\text { Wash buffer: diethanolamine (1.1 mol/1 or } 11.5 \%, \mathrm{PH} 9.8)+1 g / 1 \\
\text { sodium azide (600 } 1) .\end{array}$ \\
\hline
\end{tabular}

\section{PRINCIPLE :-}

The assay principle combines an enzyme immunoassay competition method with afinal fluorescent detection (ELFA).

The solid phase receptacle (SPR) serves as the solid phase as well as the pipetting device for the assay .

Reagent for the assay ready to use and predispensed in the seald reagent strips .

All of the assay steps are performed automatically by the instrument .

The reaction medium is cycled in and out of the SPR several times .

The sample is taken and transferred into the well containing conjugate wich is an alkaline-phosphatase labeled testosterone derivative, The testosterone present in the serum and the testosterone derivativein the conjugatecompete for the anti- testosterone specific antibody sites coated to the inner surface of the SPR .
Unbound components are eliminated during the washing steps during the final detection step the substrate (4-Methylumbelliferyl phosphate ) is cycled in and out of the SPR the conjugate enzyme catalyzed the hydrolysis of this substrate into a fluorescent product (4-Methylumbelliferone)the fluorescence of wich is measured at $450 \mathrm{~nm}$ the intensity of the fluorescence is inversely proportional to the concentration of testosterone present in the sample .

At the end pf the assay results are automatically calculated by the instrument in relation to the calibration curve stored in memory and then printed out.

\section{Methods:-}

1-only remove the required reagents from the refrigerator and allow them to come to room temperature for at least 30 minutes . 
2- use one TES strip and one TES SPR for each sample control or calibrator to be tasted .

3- type or select TES to enter the test code the calibrator must be identified by $\mathrm{S} 1$ and tasted in duplicate if the control is to be tasted it should be identified by C1.

4- Mix the samples the calibrator and/ or the control use avortix type mixer .

5- Pipette $200 \mu 1$ of sample calibrator or control into the sample well .

6- Insert the VIDAS SPRs and strip into the positions indicated on the screen check to make sure the color labels with the assay code on the SPRs and the reagent strips match .

7- Initial the assay as directed in the Operator's manual all the assay steps are performed automatically by the instrument the assay well be completed within approximately 60 minutes.

8- After the assay is completed remove the SPRs and strips from the instrument.

9- After the assay is completed Dispose of the used SPRs and strips into an appropriate recipient .
3-STATISTICAL ANALYSIS:-To be collected of the samples and STATISTICAL ANALYSIS by SPSS10 system for WINDOWS system (SPSS,chcago,lllionois and U.S.A) and the test group differentness To be STATISTICAL ANALYSIS by (independent L.S.D. and anova test) and been test moral deference under moral level (0.01) .

\section{RESULTS :-}

The total level of prolactin and testosterone were assessed in the serum of hyperprolactinemea patients and controls.

\section{The prolactin hormone}

Total patients, as well as, showed a significant $(\mathrm{P} \leq 0.01)$ increased mean serum level of prolactin $(12.9910 \pm 0.64509 \mathrm{ng} / \mathrm{ml}$,) as compared to control subjects (37.2755 $\pm 3.49557 \mathrm{ng} / \mathrm{ml}$ ). (Table -1), (figure 1)

Table - 1 - : Total serum level of prolactin in Patients and controls.

\begin{tabular}{||c|c|c|c|c||}
\hline \hline L.S.D. (0.01) & MEAN \pm S.E (NGML) & NOMBER & & \\
\hline \multirow{2}{*}{21.97} & $12.9910 \pm 0.64509$ & 20 & Control & PROLACTIN \\
\cline { 2 - 4 } & $37.2755 \pm 3.49557$ & 20 & treatment & \\
\hline
\end{tabular}

Table - 2 - : Total serum level of testosterone in Patients and controls.

\begin{tabular}{||l|l|l|l|l||}
\hline \multirow{3}{*}{ TESTOSTERONE } & & NUMRER & $\begin{array}{l}\text { MEAN } \pm \text { S.E. } \\
\text { (NGML) }\end{array}$ & L.S.D. (0.01) \\
\cline { 2 - 5 } & Control & 20 & $7.7920 \pm 0.61717$ & 3.99 \\
\cline { 2 - 4 } & treatment & 20 & $1.3845 \pm 0.84677$ & \\
\hline
\end{tabular}


The effect hyperprolactenimea on testosterone level :-

A -significant decreased serum level of testosterone $(1.3845 \pm 0.84677 \mathrm{ng} / \mathrm{ml}$ ) was observed in total patients, as well as A -significant increased serum level of prolactin $(37.2755 \pm 3.49557 \mathrm{ng} / \mathrm{ml})$ ,compared to control of testosterone $(7.7920 \pm 0.61717 \mathrm{ng} / \mathrm{ml})$ and control of prolactin ( $2.9910 \pm 0.64509 \mathrm{ng} / \mathrm{ml}$ ) . table $(1,2)$.

\section{Discussion:}

Prolactin is hormone synthesized by the anterior lobe of the pituitary gland , Prolactin is secreted in a pulsating manner ( every 20 minutes ) and follows a circadian rhythm with highest levels occurring during sleep (Ben-Jonathan, $\mathrm{N}$ et al .,1996) .Many factors control the secretion of prolactin, physiologically prolactin levels are controlled by the hypothalamus, dopamine and GABA are the main inhibitory factors, TRH ( thyrotropin-releasing hormone ) and VIP (vasoactive intestinal peptide) stimulate prolactin secretion (Bjoro et al., 1993) .

Exogenous factors such as physical exercise, stress, diet, hypoglycemia can cause an increase in prolactin levels (Biller, B. M., et al., 1999).The major physiological role of prolactin in women is the initiation and the maintenance of lactation, prolactin is also involved in follicular maturation and development of the ovum .In males prolactin affects gonadal function, hyperprolactinemia has been recognized as acause of infertility proplemes in men and women (Bjoro et al., 1993).The three etiological forms of hyperprolactinemia are iatrogenic hyperprolactinemia associated with the use of certain medications (e.g. anti-depressants , tranquilizer ), primary hyperprolactinemia associated with pituitary tumors (Allolio B et al., 1987 ), and secondary hyperprolactinemia ( hypothyroidism, renal insufficiency ). ( Brue, T. and Delemer, B. 2007).The present study showed prolactin is increased compared with the control prolactin levels have an adverse affect on the function of your testicles, and can cause decreased testosterone levels or abnormal sperm indicate a condition called hyperprolactinemia and Symptoms can include decreased sex drive impotence this due to (J Rehman et al., 2000) this study was to induce hyperprolactinemia in adult male rats and determine its effect on the central and peripheral mediated neurogenic as well as myogenic mechanisms of erectile function $\square$ dysfunction in a rat model. The use of penile reflexes in awake animals was used to test the effect of both central andperipheral echanismsHypogonadism does not seem to contribute to the impaired penile reflexes as documented by replacement of testosterone did not recover the centrally mediated penile reflexes. Lowered serum testosterone is secondary phenomenon. These observations may have important implications for the understanding, the mechanism and treatment of men with hyperprolactinemia as well as future research in this field.In another study (Spark RFet al ., 1982), as many as $100 \%$ of patients with hyperprolactinemia were impotent.The mechanism by which high serum prolactin levels cause impotence is not universally agreed upon.Interestingly, the serum testosterone level is often normal in patients with hyperprolactinemia who have impotence on presentation. Thus, in one study (Laws ER etal ., 1985), 7 of 17 patients with impotence and idiopathic hyperprolactinemia had normal serum testosterone levels Furthermore, 
bromocriptine therapy decreased serum prolactin levels and restored potency before the serum testosterone level increased into the normal range in five of six patients (Buvat J etal ., 1985). In a different study (Nagulesparen M, Ang V \& Jenkins JS .,1978), two patients with hyperprolactinemia and resistance to bromocriptine experienced no improvement in erectile function despite testosterone replacement, suggesting that hyperprolactinemia in itself may lead to erectile dysfunction irrespective of testosterone levels.And In another study Over a 4-year period, 259 men were investigated regarding primary $(86.5 \%)$ or secondary $(13.5 \%)$ infertility. Men with azoospermia had significantly higher concentrations of FSH and LH and lower concentrations of testosterone than those with spermatozoa. High concentrations of FSH and $\mathrm{LH}$ in serum were found in case of low sperm density. Men with low testicular volume had high concentrations of FSH and LH and low concentrations of testosterone. FSH was closely correlated with $\mathrm{LH}$ and also with total testicular volume. A negative correlation was found between both gonadotrophins and testosterone. The correlation between $\mathrm{LH}$ and testosterone was stronger in azoospermic men than in those with spermatozoa in semen. Serum concentrations of prolactin were higher in men with high sperm motility than among men with low motility of spermatozoa. Otherwise, prolactin concentrations were not correlated either with sperm density or with the morphology of spermatozoa or total testicular volume. A 'hormone profile' of $\mathrm{FSH}, \mathrm{LH}$ and testosterone concentrations is suggested useful in the routine investigation of the infertile man, as more information is given by this profile than by FSH concentrations
alone(L. Abramsson and M. Duchek 1988 ).In another study by (N. Binart et al.,2003) wich is show that The sleeprelated increase of plasma testosterone (T) in adult men appears to be related not only to plasma luteinizing hormone (LH) levels but to prolactin (PRL) levels as well, suggesting that PRL may have a stimulatory influence on Leydig cell function. To further investigate the influence of PRL on $\mathrm{T}$ secretion, five young adult men were studied on three separate days one week apart. Blood samples were taken every $20 \mathrm{~min}$ between 0900 and 1800. At 1000 on each of the three days they received an intramuscular injection of saline, haloperidol $0.25 \mathrm{mg}$, or haloperidol 0.50 $\mathrm{mg}$, in a double-blind design. The blood samples were analyzed for $\mathrm{LH}$, follicle stimulating hormone (FSH), PRL and T. It was hypothesized that there would be a dose-related increase in both PRL and T following drug administration. Mean PRL levels rose promptly and significantly in a dose-related manner in response to the haloperidol, which has strong dopamine blocking effects. By 1600 , PRL had returned to controlvalues. In contrast to the PRL response, neither LH nor FSH levels were affected by haloperidol. On the saline control day mean $\mathrm{T}$ levels showed the normal decline during daytime hours. After $0.25 \mathrm{mg}$ haloperidol, mean $\mathrm{T}$ levels were maintained for several hours, and after $0.50 \mathrm{mg}$ haloperidol, $\mathrm{T}$ levels were increased for several hours. These alterations in the normal diurnal pattern of $\mathrm{T}$ were statistically significant. They began about 60 min after the corresponding drug-induced increases in PRL levels. This delay between increased PRL and increased $\mathrm{T}$ is consistent with the similar delay between the increases of these two hormones that occur at night 
during sleep.The results of this study lend further support to the hypothesis that PRL is another pituitary hormone that effect $\mathrm{T}$ secretion in adult men.

\section{REFERENCES :}

Allolio B ., Hoepener A., Leonhardt U.,., Deub U ., Winkelmann W . 1987 " size heterogeneityofimmunoreactive prolactine in patients with prolactinoma". Acta Endocrinoligica (copenh), 114, 475-482.

Ben-Jonathan, N., Mershon, J. L., Allen, D.L. and Steinmetz, R.W. (1996). Extrapituitary prolactin: distribution, regulation, functions, and clinical aspects. Endocr. Rev., 17: 639-669.

Biller, B. M., Luciano, A., Crosignani, P. G., Molitch, M., Olive, D., Rebar, R., Sanfilippo, J., Webster, J. and Zacur, H. (1999). Guidelines for the diagnosis and treatment of hyperprolactinemia. J. Reprod. Med., 44: 1075-1084.

Bjoro T., Jphansen E., Frehh.H., Turter A., Torjesen P.A. ,1993, " different responses in little and big big prolactin to metoclopramide in subject $\mathrm{s}$ with hyperprolactinemia due to $150-170$ KD (bigbig) prolactin Acta endrocrinologica, 128, 308-312.

Brue, T. and Delemer, B. (2007). Diagnosis and management of hyperprolactinemia. Ann. Endocrinol., 20: 33-38.

Butt W.R. and Blunt S.M. ,1988: the role of the laboratory in the investigation of infertility ANN .clin. Biochem.,25, 601-609.

Buvat J, Lemaire A, Buvat-Herbaut M, Fourlinnie JC, Racadot A \& Fossati P. 1985 Hyperprolactinemia and sexual function in men. Hormone Research 22 196-203.

C.Bole-Feysot, V. Goffin, M. Edery, N. Binart, and P. A. Kelly Prolactin (PRL) and Its Receptor ,June 1, 1998;: Actions, Signal Transduction Pathways and Phenotypes Observed in PRL Receptor Knockout Mice Endocr. Rev., 19(3): 225 - 268.

Conn PM, Goodman HM, 1997: Handbook of Physiology: Cellular Endocrinology. Bethesda:American Physiological Society.

J.Axelsson, T. Akerstedt, G. Kecklund, A. Lindqvist, and R. Attefors, November 1, 2003;Hormonal changes in satisfied and dissatisfied shift workers across a shift cycle $J$ Appl Physiol, 95(5): 2099 - 2105.

Jones LA, Anthony JP, Henriquez FL, Lyons RE, Nickdel MB, Carter KC, Alexander J, Roberts CW. Immunology. 2008 Sep; 125(1):5969. Epub 2008 Mar 28.

J Rehman, G Christ, M Alyskewycz, E Kerr and A Melman. Experimental hyperprolactinemia in a rat model: alteration in centrally mediated neuroerectile mechanisms. February 2000, Volume 12, Number 1, Pages 23-32

L. Abramsson and M. Duchek .Gonadotropins testosterone , and prolactin in men with abnormal semen findings and an evaluationof hormone profile. department of urology and andrology, umea university hospital ,umea, sweeden. June 14 . 1988 .

Luciano, A. A. (1999). Clinical presentation of hyperprolactinemia. J. Reprod. Med., 44: 1085-1090.

Lynskey M.T.,Cahnt T.P.,Caldwell B.V. Laboratory evalution of the infertile couple and monitoring of gonadotropin therapy . jornal of clinical immunoassay . spring 1991, 14, 29-32.

Malarkey WB, Jackson R \& Wortsman J. Long-term assessment of patients with 
macroprolactinemia. Fertility and Sterility 1988, 50, 413-418.

Molitch, M. E. (2001). Disorders of prolactin secretion. Endocrinol. Metab. Clin. North. Am., 30: 585610.

Nagulesparen M, Ang V \& Jenkins JS. Bromocriptine treatment of males with pituitary tumours, hyperprolactinaemia, and hypogonadism. Clinical Endocrinology 19789 73-79.

N.Binart, N. Melaine, C. Pineau, H. Kercret, A. M. Touzalin, P. Imbert-Bollore, P. A. Kelly, and B. Jegou Male Reproductive Function Is Not Affected in Prolactin Receptor-Deficient Mice Endocrinology,
September 1, 2003; 144(9): 3779 3782.

Spark RF, Wills CA, O’Reilly G, Ransil BJ \& Bergland R. Hyperprolactinemia in males with and without pituitary macroadenomas. Lancet 19822 129-132.

Thomson RC: Biomaterials Regulating Cell Function and Tissue Development.Warrendale, PA: Materials Research Society, 1998.

W.A. Brown, T. P. Laughren, and B. Williams .Differential Effects of Neuroleptic Agents on the Pituitary-Gonadaln Axis in Men Arch Gen Psychiatry, November 1, 1981; 38(11): 1270 1272.

\section{در اسة تأثثر زيادة هرمون البرو لاكتين عند الرجال العقيمين وتأثيره على مستوى هرمون التستيستيرون.}

$$
\begin{aligned}
& \text { إيناس عبد الكريم جبار } \\
& \text { قسم علوم الحياة - كلية العلوم - جامعة ذي قار }
\end{aligned}
$$

\section{الخلاصة}

صممت الدراسة الحالية لكثف تركيز مستوى هرمون التسنيستيرون testosterone عند ارتفاع هرمون البرولاكتين

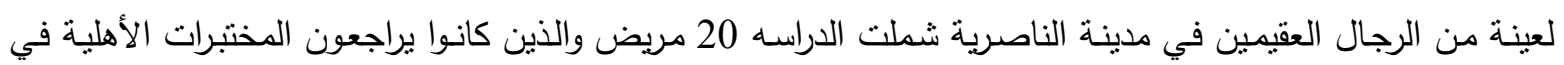

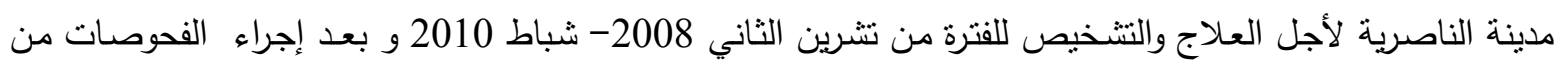

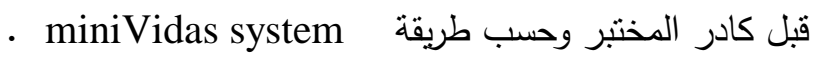
لوحظ إن الارتفاع في مستوى هرمون البرولاكتين prolactin في دم الرجال الذين يعانون مشاكل في الخصوبة يسبب

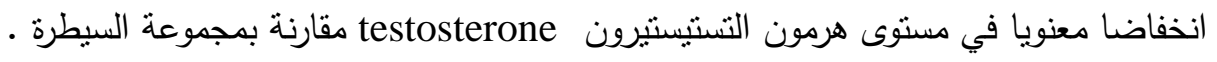

